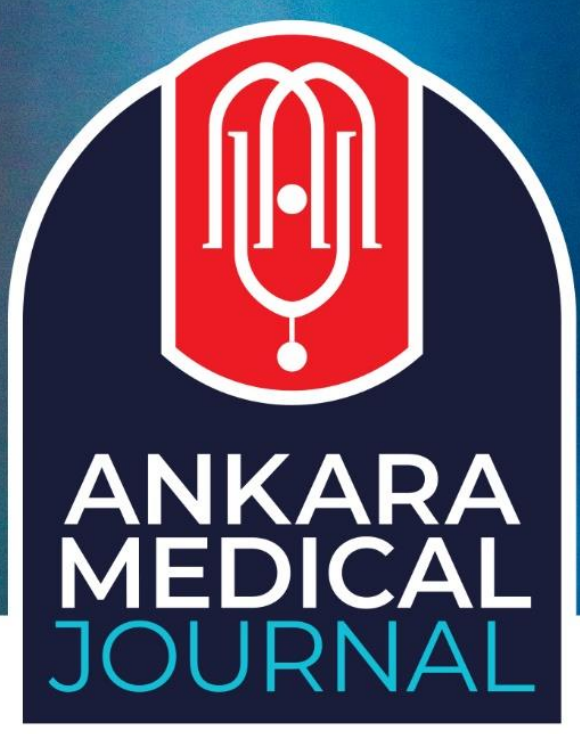

Research Article

Ankara Med J, 2020;(1):170-179 // (60) 10.5505/amj.2020.35492

\title{
The Relationship Between Hypothyroidism and Body Fat Mass and Metabolic Parameters by Gender in Patients with Type 2 Diabetes Mellitus
}

\section{Tip 2 Diabetes Mellitusta Cinsiyetlere Göre Hipotiroidi ile Vücut Yağ Kitlesi ve Metabolik Parametreler İlişkisi}

\section{Emrah Tekin ${ }^{1}$, (D) Sabah Tüzün11, (D) Hüseyin Çetin1, (D) Engin Ersin Şimşek1 \\ ${ }^{1}$ Kartal Dr. Lutfi Kirdar Training and Research Hospital}

Yazıșma Adresi / Correspondence:

Sabah Tüzün (e-mail: (sabahtuzun@gmail.com)

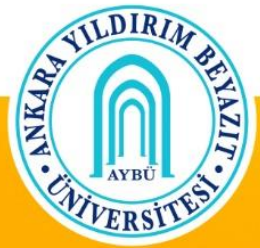




\title{
Öz
}

Amaç: Tiroid hormonu vücut metabolizmasının düzenlenmesinde önemli rol oynamakta ve tiroid bezi disfonksiyonu diabetes mellitus (DM) olan bireylerde sık gözlenmektedir. Bu çalışmada DM hastalarında hipotiroidi ile vücut yağ kitlesi ve metabolik parametreler arasındaki ilişkisinin değerlendirilmesi amaçlanmaktadır.

Materyal ve Metot: Çalışmaya hastanemiz Diyabet Ünitesi'ne Aralık 2017-Mayıs 2018 tarihleri arasında başvuran, 18 yaş ve üzeri DM hastaları kabul edilmiștir. Tüm katılımcıların dosyaları retrospektif olarak değerlendirilmiştir. Tüm katılımcılar hipotiroidi varlığına göre iki gruba ayrılmıştır. Tüm katılımcıların biyoempedans analiz yöntemi ile vücut yağ kitlesi ölçümleri olarak vücut kitle indeksi (VKI)), toplam ekstremite yağ kitlesi (TEYK), toplam yağ kitlesi (TYK), gövde yağ kitlesi (GYK) ve vücut yağ yüzdesi (VYY) ölçülmüsstür. Ayrıca katılımcların metabolik parametrelerinden HbA1c, trigliserid, LDL-kolesterol, HDL-kolesterol ve Cpeptit düzeyleri de değerlendirilmiştir. Hipotiroidi tedavisindeki hedef TSH düzeyleri genç ve orta yaşlı bireylerde $0,4-2,5 \mathrm{mU} / \mathrm{mL}, 65-80$ yaş arası bireylerde $3-6 \mathrm{mU} / \mathrm{mL}$ ve 80 yaş üzeri bireylerde $\leq 10 \mathrm{mU} / \mathrm{mL}$ olarak belirlenmiştir.

Bulgular: Çalışmaya toplam 620 DM hastası dahil edilmiş ve katılımcıların $141(\% 22,74)$ 'de hipotiroidi bulunmuştur. Hipotiroidi olan katılımcıların $55(\% 39,01)$ 'de de tiroid regülasyonu saptanmıştır. Hipotirodi olan kadınlarda VKi $35,18 \pm 6,03 \mathrm{~kg} / \mathrm{m}^{2}$ iken, olmayanlarda $33,79 \pm 6,19 \mathrm{~kg} / \mathrm{m}^{2}$ olarak saptanmıştır $(\mathrm{p}=0.035)$. Erkeklerde ise hipotiroidi olanlarda VKI $30,58 \pm 3,85 \mathrm{~kg} / \mathrm{m}^{2}$ ve olmayanlarda $30,75 \pm 4,80 \mathrm{~kg} / \mathrm{m}^{2}$ olarak gözlenmiştir $(p=0,865)$. Hipotiroidi olan kadınlarda HbA1c \%7,51 $\pm 1,91$; olmayanlarda $\% 8,12 \pm 2,02$ olarak saptanmıștır $(\mathrm{p}=0,004)$. Bununla beraber tiroid regülasyonu olan kadınlarda HbA1c \%6,73 \pm 1.21 ve olmayanlarda $\% 7,95 \pm 2,10$ olarak tespit edilmiştir $(\mathrm{p}=0,001)$.

Sonuç: Hipotiroidi olan kadınlarda VKİ ve toplam ekstremite yağ kitlesi anlamlı yüksek iken, erkeklerde benzer farklılık saptanmamıştır. Ayrıca hipotiroidi olmayan kadınlarda HbA1c yüksek saptanmakla beraber, tiroid regülasyonu olanlarda $\mathrm{HbA1c}$ düşük bulunmuștur. Bununla beraber erkeklerde ise, hipotiroidi varlığı ve tiroid regülasyonu açısından $\mathrm{HbA1c}$ düzeyinde fark tespit edilmemiştir.

Anahtar Kelimeler: Tip 2 diabetes mellitus, hipotiroidizm, yağ dokusu, abdominal yağ.

\begin{abstract}
Objectives: The thyroid hormone plays a significant role in the regulation of body metabolism and thyroid gland dysfunction is commonly seen in individuals with diabetes mellitus (DM). This study aims to evaluate the relationship between hypothyroidism, body fat mass (BFM) and metabolic parameters in patients with DM.

Materials and Methods: The study included patients with DM aged 18 years and above, who admitted to the Diabetes Unit of our hospital between December 2017 and May 2018. The files of all participants were reviewed retrospectively. All participants included in the study were divided into two groups according to the presence of hypothyroidism. Body mass index (BMI), total extremity fat mass (TEFM), total body fat mass (TBFM), trunk fat mass (TFM) and body fat percentage (BFP) of all participants were measured by bioelectrical impedance analysis. Hemoglobin A1c (HbA1c), triglyceride, low-density lipoprotein (LDL) cholesterol, highdensity lipoprotein (HDL) cholesterol and C-peptide levels of the patients were evaluated. Targeted TSH levels in the treatment of hypothyroidism were defined $0.4-2.5 \mathrm{mU} / \mathrm{mL}$ in young and middle-aged individuals, 3-6 $\mathrm{mU} / \mathrm{mL}$ in the $65-80$ years of age, and $\leq 10 \mathrm{mU} / \mathrm{mL}$ in individuals older than 80 years of age.

Results: A total of 620 patients with DM were included in the study and $141(22.74 \%)$ of them had hypothyroidism. Thyroid regulation was achieved in 55 (39.01\%) of the participants with hypothyroidism. Of female patients with hypothyroidism, BMI was $35.18 \pm 6.03 \mathrm{~kg} / \mathrm{m}^{2}$, while it was $33.79 \pm 6.19 \mathrm{~kg} / \mathrm{m}^{2}$ in patients without hypothyroidism ( $\mathrm{p}=0.035$ ). In male patients with hypothyroidism, BMI was $30.58 \pm 3.85 \mathrm{~kg} / \mathrm{m}^{2}$, while it was $30.75 \pm 4.80 \mathrm{~kg} / \mathrm{m}^{2}$ in patients without hypothyroidism ( $\left.\mathrm{p}=0.865\right)$. In female patients with and without hypothyroidism, HbA1c was $7.51 \pm 1.91 \%$ and $8.12 \pm 2.02 \%$, respectively $(\mathrm{p}=0.004)$. However, in female patients with and without thyroid regulation, $\mathrm{HbA1c}$ was $6.73 \pm 1.21 \%$ and $7.95 \pm 2.10 \%$, respectively $(\mathrm{p}=0.001)$.

Conclusion: In females with hypothyroidism, BMI and TEFM were significantly higher, while there was no such difference in males. Furthermore, HbA1c levels were higher in females without hypothyroidism and HbA1c was lower in those with thyroid regulation. No significant difference was observed in terms of HbA1c levels in males with hypothyroidism.
\end{abstract}

Keywords: Type 2 Diabetes Mellitus, hypothyroidism, adipose tissue, abdominal fat. 


\section{Introduction}

Thyroid hormone with catabolic effect plays a significant role in the regulation of basal metabolism. ${ }^{1}$ Hypothyroidism, which is frequently observed in individuals with type 2 diabetes mellitus (DM), leads to a reduction in energy consumption, weight gain, increase in cholesterol levels, and reduction in lipolysis and gluconeogenesis. ${ }^{1,2}$ Thyroid-stimulating hormone (TSH) has been reported to be associated with impaired metabolic parameters in patients with DM. ${ }^{2}$ In a study, abnormal TSH levels were observed in $30 \%$ of DM patients with poor blood glucose regulation, however, these levels were reported to be returned to normal when blood glucose regulation was brought under control. ${ }^{1}$ In the same study, a relationship was reported between thyroid hormones and lipid metabolism in patients with thyroid dysfunction. ${ }^{1}$ The increase in TSH level, together with insulin resistance, is thought to cause dyslipidemia in patients with DM. ${ }^{2}$ The aim of this study is to evaluate the relationship between hypothyroidism and body fat mass (BFM) and metabolic parameters in DM patients by gender.

\section{Materials and Methods}

Patients with DM aged 18 years and older, who were admitted to the diabetes unit between December 2017 and May 2018, were included in the study. The files of all participants were reviewed retrospectively, and the patients were divided into two groups according to the presence of primer hypothyroidism.

\section{Measurement methods}

Bodyweight, body mass index (BMI), total extremity fat mass (TEFM), total body fat mass (TBFM), trunk fat mass (TFM), and body fat percentage (BFP) of all patients were determined by bioelectrical impedance analysis (BIA) method using TANITA Body Composition Analyzer Type BC-418 MA (Tanita Corporation of America, Inc. Illinois, USA). Age, gender, duration of DM, duration of hypothyroidism, and the weekly dose of levothyroxine were recorded. After 12 hours of fasting, HbA1c (Premier Hb9210, Trinity Biotech, Ireland), C-peptide (Roche Modular E170, Roche Diagnostics, Switzerland), triglyceride (Beckman Coulter AU 5800, Brea, CA, USA), LDLcholesterol (Beckman Coulter AU 5800, Brea, CA, USA), HDL-cholesterol (Beckman Coulter AU 5800, Brea, CA, USA) and TSH (Beckman Coulter Uni Cel dxl800, Brea, CA, USA) levels were measured. TSH levels were defined as hypothyroidism above $10 \mathrm{mU} / \mathrm{mL}$ in all participants and $4-10 \mathrm{mU} / \mathrm{mL}$ in patients with symptoms. ${ }^{3}$ Targeted TSH level was $0.4-2.5 \mathrm{mU} / \mathrm{mL}$ in young and middle-aged individuals, $3-6 \mathrm{mU} / \mathrm{mL}$ in the $65-80$ years of age, and $\leq 10 \mathrm{mU} / \mathrm{mL}$ in individuals older than 80 years of age. ${ }^{3}$ 


\section{Exclusion criteria}

Patients with type 1 DM, chronic liver failure, chronic renal failure, and pregnancy were excluded from the study.

\section{Statistical analysis}

Statistical analysis was performed using SPSS version 15.0 software. Descriptive data were expressed as frequency and percentage for categorical variables; mean and standard deviation for variables with normal distribution; median, minimum and maximum for variables with the abnormal distribution. KolmogorovSmirnov Test and Shapiro Wilk test were used to determine the normality of the quantitative data. During the comparative analysis, Student's t-test and Pearson's correlation test were used for continuous variables with normal distribution, while the Mann-Whitney U test and Spearman correlation analysis were used for nonnormally distributed variables. A p-value of $<0.05$ was considered statistically significant.

\section{Ethical Considerations}

The study was approved by the local ethics committee (Protocol Number: 2018/514/122/23, Approval Date: 31.01.2018).

\section{Results}

A total of 620 patients with DM were included in the study and 141 (22.74\%) of them had hypothyroidism. The duration of DM in female patients with and without hypothyroidism was 10.0 (1.0-35.0) years and 9.5 (1.037.0) years, respectively $(\mathrm{p}=0.297)$. Besides, the duration of $\mathrm{DM}$ in male patients with and without hypothyroidism was 10.5 (1.0-26.0) years and 6.0 (1.0-32.0) years, respectively ( $\mathrm{p}=0.028)$. The duration of hypothyroidism in female and male participants was 10.0 (1.0-37.0) years and 6.0 (1.0-36.0) years, respectively ( $\mathrm{p}=0.001)$. The weekly dose was $700.0(175.0-2100.0) \mathrm{mcg}$ and 700.0 (175.0-1400.0) $\mathrm{mcg}$ in female and male participants, respectively $(\mathrm{p}=0.001)$. Baseline age, body fat measurements and laboratory parameters according to thyroid status and gender are summarized in Table 1.

Out of 141 participants with hypothyroidism, 55 (39.01\%) of them reached thyroid regulation. The duration of DM in female patients with and without hypothyroidism was 8.0 (1.0-25.0) years and 10.0 (1.0-35.0) years $(\mathrm{p}=0.297)$. The duration of DM in male patients with and without thyroid regulation was 10.0 (1.0-26.0) years and $13.0(7.0-24.0)$ years $(\mathrm{p}=0.028)$. No significant difference was observed in terms of the duration of hypothyroidism and weekly dose between the patients with and without thyroid regulation in both genders. Age, body fat measurements and laboratory parameters in terms of thyroid regulation by gender are 
summarized in Table 2. Besides, the relationship TSH between metabolic parameters and body fat measurements according to the presence of hypothyroidism and thyroid regulation in both genders are summarized in Table 3.

In females with thyroid regulation, the weekly dose was correlated with BMI and TEFM ( $\mathrm{r}=0.362$, p=0.014 and $r=0.308, p=0.039)$ whereas no correlation was observed in male patients $(p=0.702$ and $p=0.629)$. In females without thyroid regulation, a relationship was observed between the weekly dose and TEFM (r=0.257, $\mathrm{p}=0.023)$, whereas no relationship was observed in male patients $(\mathrm{p}=0.998)$. No statistically significant relationship was found between the duration of hypothyroidism, metabolic parameters, and body fat measurements in both genders.

Table 1. Baseline age, body fat measurements and laboratory parameters according to thyroid status and gender

\begin{tabular}{|c|c|c|c|c|c|c|}
\hline & \multicolumn{3}{|c|}{ Female $(n=406)$} & \multicolumn{3}{|c|}{ Male $(n=214)$} \\
\hline & Hypoth & coidism & \multirow{3}{*}{$\mathbf{p}$} & Hypoth & roidism & \multirow{3}{*}{$\mathbf{p}$} \\
\hline & \multicolumn{2}{|c|}{ Mean \pm Standard deviation } & & \multicolumn{2}{|c|}{ Mean \pm Standard deviation } & \\
\hline & $\begin{array}{c}\text { No } \\
(n=283) \\
\end{array}$ & $\begin{array}{c}\text { Yes } \\
(n=123) \\
\end{array}$ & & $\begin{array}{c}\text { No } \\
(n=196) \\
\end{array}$ & $\begin{array}{c}\text { Yes } \\
(n=18) \\
\end{array}$ & \\
\hline Age (years) & $58.33 \pm 9.63$ & $57.70 \pm 9.62$ & 0.543 & $56.15 \pm 10.01$ & $60.39 \pm 8.23$ & 0.053 \\
\hline BMI $\left(\mathrm{kg} / \mathrm{m}^{2}\right)$ & $33.79 \pm 6.19$ & $35.18 \pm 6.03$ & $0.035^{*}$ & $30.75 \pm 4.80$ & $30.58 \pm 3.85$ & 0.865 \\
\hline TBFM (kg) & $34.20 \pm 10.64$ & $36.35 \pm 10.30$ & 0.057 & $25.13 \pm 9.47$ & $25.00 \pm 7.56$ & 0.942 \\
\hline TEFM (kg) & $18.47 \pm 6.36$ & $19.83 \pm 6.33$ & $0.049^{*}$ & $9.94 \pm 4.55$ & $10.08 \pm 4.41$ & 0.892 \\
\hline TFM (kg) & $15.69 \pm 4.74$ & $16.68 \pm 4.62$ & 0.052 & $15.36 \pm 5.25$ & $14.95 \pm 4.00$ & 0.688 \\
\hline BFP (\%) & $41.06 \pm 5.71$ & $42.04 \pm 5.11$ & 0.089 & $27.63 \pm 6.36$ & $27.54 \pm 5.10$ & 0.942 \\
\hline HbA1c (\%) & $8.12 \pm 2.02$ & $7.51 \pm 1.91$ & $0.004^{*}$ & $8.08 \pm 2.15$ & $7.47 \pm 1.50$ & 0.126 \\
\hline $\begin{array}{l}\text { LDL-cholesterol } \\
\text { (mg/dL) }\end{array}$ & $132.30 \pm 48.96$ & $140.58 \pm 40.91$ & 0.079 & $128.58 \pm 37.79$ & $114.61 \pm 30.54$ & 0.083 \\
\hline $\begin{array}{l}\text { HDL-cholesterol } \\
(\mathrm{mg} / \mathrm{dL})\end{array}$ & $49.48 \pm 10.54$ & $50.74 \pm 11.25$ & 0.289 & $43.33 \pm 9.30$ & $40.22 \pm 8.66$ & 0.162 \\
\hline \multirow[t]{2}{*}{ C-peptide $(\mu \mathrm{g} / \mathrm{L})$} & $2.74 \pm 1.24$ & $2.87 \pm 1.29$ & 0.345 & $2.77 \pm 1.10$ & $2.58 \pm 1.13$ & 0.517 \\
\hline & \multicolumn{2}{|c|}{ Median (min-max) } & $\mathbf{p}$ & \multicolumn{2}{|c|}{ Median (min-max) } & $\mathbf{p}$ \\
\hline $\begin{array}{l}\text { Triglyceride } \\
\text { (mg/dL) }\end{array}$ & $\begin{array}{c}147.00 \\
(48.00- \\
1465.00) \\
\end{array}$ & $\begin{array}{c}147.00 \\
(74.00- \\
956.00) \\
\end{array}$ & $0.415^{\dagger}$ & $\begin{array}{l}144.00 \\
(60.00- \\
944.00)\end{array}$ & $\begin{array}{c}133.50 \\
(90.00- \\
1656.00) \\
\end{array}$ & $0.764^{\dagger}$ \\
\hline TSH (uIU/mL) & $\begin{array}{c}1.74 \\
(0.09-5.75)\end{array}$ & $\begin{array}{c}2.54 \\
(0.05-49.5)\end{array}$ & $0.003^{+}$ & $\begin{array}{c}1.56 \\
(0.09-8.08)\end{array}$ & $\begin{array}{c}2.31 \\
(0.11-6.97)\end{array}$ & $0.081^{\dagger}$ \\
\hline
\end{tabular}

TBFM: Total Body Fat Mass, TEFM: Total Extremity Fat Mass, TFM: Trunk Fat Mass, TSH: Thyroid-Stimulating Hormone, BMI: Body Mass Index, BFP: Body Fat Percentage

${ }^{*}$ Student's t-test; †Mann Whitney U test 
Table 2. Age, body fat measurements and laboratory parameters in terms of thyroid regulation by gender

\begin{tabular}{|c|c|c|c|c|c|c|}
\hline & \multicolumn{3}{|c|}{ Female $(n=123)$} & \multicolumn{3}{|c|}{ Male $(n=18)$} \\
\hline & \multirow{2}{*}{\multicolumn{2}{|c|}{$\begin{array}{c}\text { Hypothyroidism control } \\
\text { Mean } \pm \text { Standard deviation }\end{array}$}} & \multirow{3}{*}{$\mathbf{p}$} & \multirow{2}{*}{\multicolumn{2}{|c|}{$\begin{array}{c}\text { Hypothyroidism control } \\
\text { Mean } \pm \text { Standard deviation }\end{array}$}} & \multirow{3}{*}{$\mathbf{p}$} \\
\hline & & & & & & \\
\hline & $\begin{array}{c}\text { No } \\
(n=78)\end{array}$ & $\begin{array}{c}\text { Yes } \\
(n=45)\end{array}$ & & $\begin{array}{c}\text { No } \\
(n=8)\end{array}$ & $\begin{array}{c}\text { Yes } \\
(n=10)\end{array}$ & \\
\hline Age (years) & $57.25 \pm 9.65$ & $58.46 \pm 9.63$ & 0.504 & $64.30 \pm 6.00$ & $55.50 \pm 8.31$ & $0.027^{*}$ \\
\hline BMI $\left(\mathrm{kg} / \mathrm{m}^{2}\right)$ & $35.42 \pm 6.57$ & $34.76 \pm 4.98$ & 0.527 & $30.68 \pm 4.15$ & $30.51 \pm 3.83$ & 0.932 \\
\hline TBFM (kg) & $36.87 \pm 11.27$ & $35.46 \pm 8.41$ & 0.432 & $24.28 \pm 7.45$ & $25.57 \pm 7.99$ & 0.730 \\
\hline TEFM (kg) & $20.13 \pm 7.03$ & $19.30 \pm 4.92$ & 0.445 & $10.40 \pm 4.98$ & $9.84 \pm 4.17$ & 0.803 \\
\hline TFM (kg) & $16.97 \pm 5.00$ & $16.18 \pm 3.89$ & 0.333 & $13.91 \pm 3.92$ & $15.78 \pm 4.07$ & 0.339 \\
\hline BFP (\%) & $42.29 \pm 5.37$ & $41.61 \pm 4.65$ & 0.465 & $25.65 \pm 5.87$ & $29.06 \pm 4.07$ & 0.188 \\
\hline HbA1c (\%) & $7.95 \pm 2.10$ & $6.73 \pm 1.21$ & $0.001^{*}$ & $7.88 \pm 1.70$ & $7.14 \pm 1.32$ & 0.327 \\
\hline $\begin{array}{l}\text { LDL-cholesterol } \\
\text { (mg/dL) }\end{array}$ & $137.38 \pm 41.83$ & $146.14 \pm 39.10$ & 0.246 & $113.75 \pm 26.87$ & $\begin{array}{c}115.30 \pm 34 \\
62\end{array}$ & 0.916 \\
\hline $\begin{array}{l}\text { HDL- } \\
\text { cholesterol } \\
(\mathrm{mg} / \mathrm{dL}) \\
\end{array}$ & $52.51 \pm 12.08$ & $47.68 \pm 8.96$ & $0.013^{*}$ & $35.12 \pm 6.79$ & $44.30 \pm 8.02$ & $0.018^{*}$ \\
\hline \multirow[t]{2}{*}{$\begin{array}{l}\text { C-peptide } \\
(\mu \mathrm{g} / \mathrm{L})\end{array}$} & $2.80 \pm 1.36$ & $3.00 \pm 1.18$ & 0.402 & $2.65 \pm 1.25$ & $2.54 \pm 1.09$ & 0.839 \\
\hline & \multicolumn{2}{|c|}{ Median (min-max) } & & \multicolumn{2}{|c|}{ Median (min-max) } & \\
\hline $\begin{array}{l}\text { Triglyceride } \\
\text { (mg/dL) }\end{array}$ & $\begin{array}{c}147.00 \\
(75.00-956.00)\end{array}$ & $\begin{array}{l}146.00 \\
(74.00- \\
509.00)\end{array}$ & 0.415 & $\begin{array}{c}153.00 \\
(90.00- \\
1656.00)\end{array}$ & $\begin{array}{l}125.00 \\
(98.00- \\
222.00)\end{array}$ & 0.767 \\
\hline TSH (uIU/mL) & $\begin{array}{c}3.19 \\
(0.05-49.5)\end{array}$ & $\begin{array}{c}1.67 \\
(0.43-6.91)\end{array}$ & $0.011^{\dagger}$ & $\begin{array}{c}5.35 \\
(0.11-6.97)\end{array}$ & $\begin{array}{c}1.63 \\
(0.56-4.36)\end{array}$ & 0.146 \\
\hline
\end{tabular}

TBFM: Total Body Fat Mass, TEFM: Total Extremity Fat Mass, TFM: Trunk Fat Mass, TSH: Thyroid-Stimulating Hormone, BMI: Body Mass Index, BFP: Body Fat Percentage

${ }^{*}$ Student's t-test; †Mann Whitney U test 
Table 3. The relationship TSH between metabolic parameters and body fat measurements according to the presence of hypothyroidism and thyroid regulation

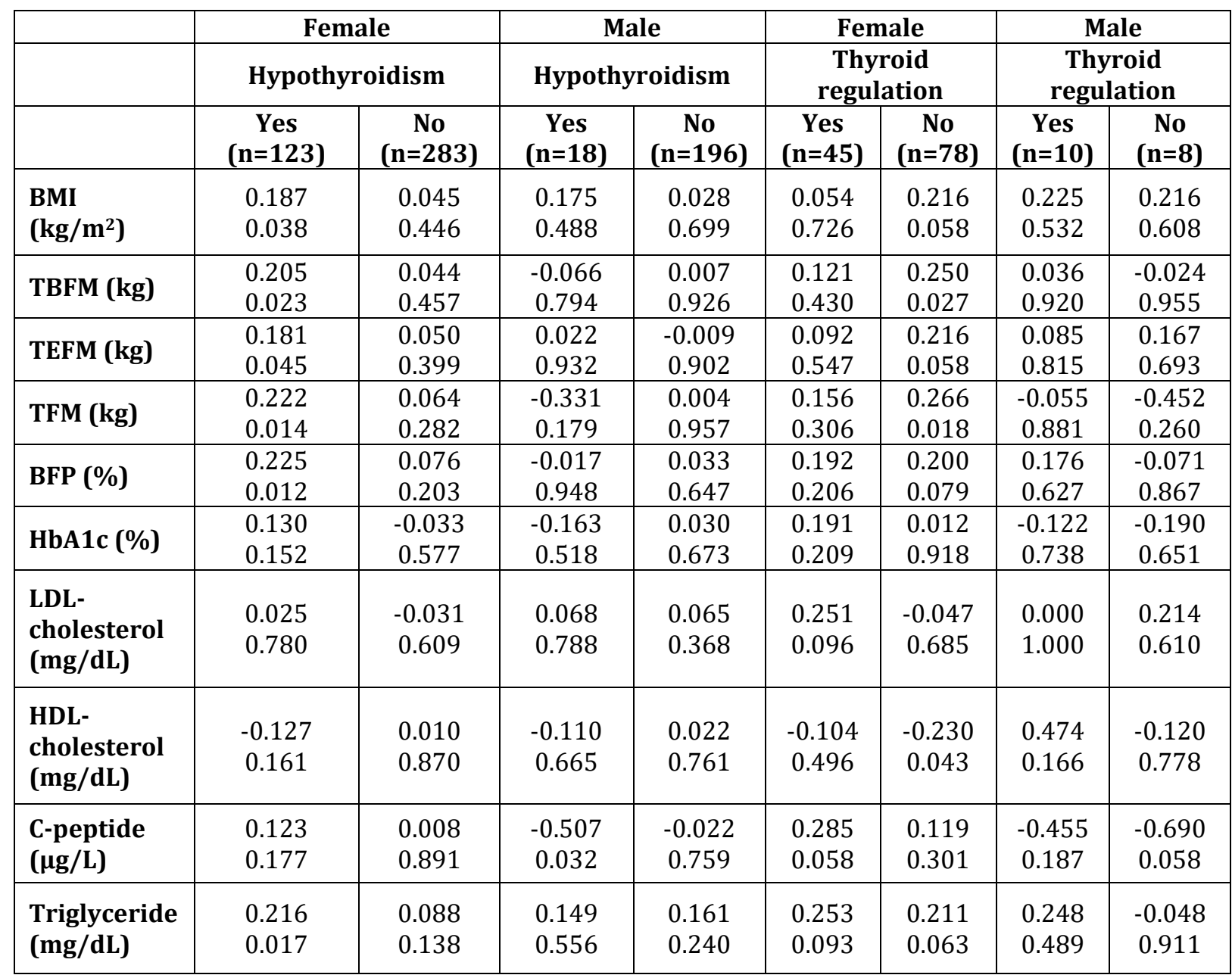

BMI: Body Mass Index, BFP: Body Fat Percentage, TBFM: Total Body Fat Mass, TEFM: Total Extremity Fat Mass, TFM: Trunk Fat Mass

Spearman correlation test. The data were presented as $r$ values and $p$ values.

\section{Discussion}

The aim of this study is to evaluate the relationship between hypothyroidism, BFM, and metabolic parameters in DM patients by gender. In light of the information obtained from the study, BMI and TEFM were higher in female patients with hypothyroidism, whereas no difference was observed in male participants. In female patients with thyroid regulation, BMI, TBFM, TEFM, and BFP levels were low but not statistically significant. Considering the metabolic parameters, HbA1c levels were significantly lower in females with hypothyroidism, while no significant difference was seen in males. Furthermore, HbA1c levels were lower in patients with 
thyroid regulation compared to those without thyroid regulation, which was statistically significant only in females.

The relationship between TSH level and BMI is highly controversial. ${ }^{4-12}$ In a study comparing patients with hypothyroidism and healthy individuals, BMI was higher in patients with hypothyroidism. ${ }^{4}$ In some studies, a positive correlation was reported between TSH and BMI, whereas a negative correlation was reported only in a study. ${ }^{5-9}$ In other studies, however, no relationship was observed between TSH and BMI levels. ${ }^{10-12}$ In the present study, BMI levels were statistically significantly higher in female patients with hypothyroidism, however, no difference was observed in males. This difference might be attributed to the fact that the prevalence of obesity is more common in females than males. Another reason might be the fact that the TSH level used in the evaluation of thyroid regulation was affected by age and gender. ${ }^{13,14}$ As the age increases, the TSH level also increases. ${ }^{13}$ In our study, there was no significant difference in age between patients with and without hypothyroidism in both genders.

In a prospective study of individuals with hypothyroidism, no change was reported in BMI levels in their 6thand 18th-month follow-up controls. ${ }^{4}$ However, in another study, BMI levels were higher in individuals receiving L-thyroxine therapy of less than two years. ${ }^{15}$ In a study, L-thyroxine therapy was found to cause an increase in BMI independently from TSH. ${ }^{16}$ In our study, there was a positive correlation between TSH and BMI in females with hypothyroidism, however, no correlation was observed in males. It was further observed that BMI was correlated with weekly dose in females with thyroid regulation, whereas no correlation was observed in males. This might be attributed to the fact that the weekly dose in females was higher than the dose received by male participants.

In the literature or previous reports with hypothyroidism, BFM and BFP were higher than healthy individuals and a positive correlation was observed between TSH and BFP levels. ${ }^{4,7,17}$ In the present study, no significant difference was found between the two groups with and without hypothyroidism in terms of BFP. Furthermore, no significant difference was observed between the patients with and without thyroid regulation in terms of BFP. This difference might be attributed to the fact that we included patients with DM, unlike other studies. Obesity and high BFP are important risk factors for DM. ${ }^{2}$ Therefore, DM may have been a confusing factor in our study. In a study, no change was reported in terms of BFP at the 6th-and 18th-month follow-up controls of patients with hypothyroidism. ${ }^{15}$ In other studies, L-thyroxine therapy was reported to have no effect on BFM, body weight and BFP.15,18In our study, there was no relationship between BFP, duration of hypothyroidism, and weekly dose.

In the literature, the relationship between TSH and metabolic parameters is controversial. ${ }^{11,19,20}$ In some studies, no relationship was found between TSH, fasting plasma glucose, and HbA1c levels, whereas a negative 
correlation was reported in some studies. ${ }^{5,9-11,20}$ In our study, the HbA1c level was low in patients with hypothyroidism in both genders, which was statistically significantly lower only in females. Furthermore, HbA1c level low in patients with thyroid regulation, which statistically significantly lowered only in females. In a study, the interaction between thyroid function and insulin resistance in individuals with DM contributed to dyslipidemia. ${ }^{2}$ Studies have reported a correlation between TSH level, triglyceride, and LDL-cholesterol levels.5,6,10,11,19,20 A positive correlation was reported between TSH and LDL-cholesterol in a study, but no relationship was found when it was rearranged with age and BMI. ${ }^{21}$ Furthermore, there are also studies reporting a negative correlation between TSH and HDL-cholesterol levels. $5,9,20$ In the present study, no statistically significant difference was found between the two groups with and without hypothyroidism in terms of lipid profile. In patients with thyroid regulation, there was no difference in terms of LDL-cholesterol and triglyceride levels, whereas HDL-cholesterol was lower in females with thyroid regulation and higher in males. The reason for these differences might be attributed to the fact that during the study, interventions such as nutrition, exercise, and medical treatment for DM and dyslipidemia were continued.

There are some limitations to our study. Firstly, free triiodothyronine and free thyroxine levels of the patients were not evaluated. Secondly, lifestyle changes, such as nutrition and exercise, and medical treatments were continued for all participants during the course of the study. Thirdly, the number of male participants in this study was small.

In conclusion, the dysfunction of the thyroid plays an important role in the regulation of metabolism is commonly seen in individuals with DM.1,2 In the present study, in females with DM and hypothyroidism, BMI and TEFM levels were significantly higher, while there was no such difference in males. Furthermore, there was no difference in body fat measurements between patients with and without thyroid regulation in both genders. Considering the HbA1c levels among the metabolic parameters, HbA1c levels were high in females without hypothyroidism and HbA1c was lower in patients with thyroid regulation. 


\section{References}

1. Mullur R, Liu YY, Brent GA. Thyroid hormone regulation of metabolism. Physiol Rev 2014;94:35-82.

2. Sabuncu T, Eren MA, Torun AN, Ulaş T,Kök EK. Yeni Tanı Almış Tip 2 Diyabetiklerde TSH ile Vücut Kompozisyonu ve Metabolik Belirteçler Arasındaki İlişki. Turkiye Klinikleri J Endocrin 2011;6(2):559.

3. Tiroid Hastalıkları Tanı ve Tedavi Kılavuzu 2017. Türkiye Endokrinoloji ve Metabolizma Derneği. Ortadoğu Reklam Tanıtım Yayıncılık Turizm Eğitim İnşaat Sanayi ve Ticaret AŞ. Baskı 1. Ankara, Türkiye. 2017;48.

4. Popławska-Kita A, Siewko K, Telejko B, et al. Body mass analysis in patients with Hashimoto thyroiditis. Prog Health Sci 2014;4:1:18-23.

5. Wolffenbuttel BHR, Wouters HJCM, Slagter SN, et al. Thyroid function and metabolic syndrome in the population-based Life Lines cohort study. BMC Endocr Disord 2017;17(1):65.

6. Oh JY, Sung YA, Lee HJ. Elevated thyroid stimulating hormone levels are associated with metabolic syndrome in euthyroid young women. Korean J Intern Med 2013;28(2):180-6.

7. Mukherjee S, Mukhopadhyay D, Chakraborty P. Relationship between Body Mass Index (BMI), Body Fat Percent and Serum TSH Level in Euthyroid Female Subjects. Int J SciRes 2015;4:6:1697-1700.

8. Knudsen N, Laurberg P, Rasmussen LB, et al. Small differences in thyroid function may be important for body mass index and the occurrence of obesity in the population. J Clin Endocrinol Metab 2005;90:4019-24.

9. Kim HJ, Bae JC, Park HK, et al. Triodothyronine levels are independently associated with metabolic syndrome in Euthyroid middle-aged subjects. Endocrinol Metab (Seoul) 2016;31:311-9.

10. Park HT, Cho GJ, Ahn KH, et al. Thyroid stimulating hormone is associated with metabolic syndrome in euthyroid postmenopausal women. Maturitas 2009;62:301-5.

11. Waring AC, Rodondi N, Harrison S, et al.Thyroid function and prevalent and incident metabolic syndrome in older adults: the health, ageing and body composition study. Clin Endocrinol 2012;76:911-8.

12. Rotondi M, Leporati P, La Manna A, et al. Raised serum TSH levels in patients with morbid obesity: is it enough to diagnose subclinical hypothyroidism? Eur J Endocrinol 2009;160:403-8.

13. Kaur G, Kalsotra L, Sadhoo AK. Age and Sex Related Changes in Thyroid Functions in Normal Healthy Subjects of Jammu Region. JK SCIENCE 2007;9:3:132-6.

14. Lai Y, Wang J, Jiang F, Wang B, Chen Y, Li M. The relationship between serum thyrotropin and components of metabolic syndrome. Endocrine Journal 2011;58(1): 23-30.

15. Bakiner O, Bozkirli E, Ersozlu Bozkirli ED, Ozsahin K. Correction of Hypothyroidism Seems to Have No Effect on Body Fat. Int J Endocrinol 2013;2013:576794. 
16. Ruhla S, Arafat AM, Osterhoff M, et al. Levothyroxine medication is associated with adiposity independent of TSH. Exp Clin Endocrinol Diabetes 2012;120(6):351-4.

17. Krotkiewski M. Thyroid hormones in the pathogenesis and treatment of obesity.Eur J Pharmacol 2002;440(2-3):85-98

18. Karakoc A, Ayvaz G, Taneri F, et al. The effects of hypothyroidism in rats on serum leptin concentrations and leptin mRNA levels in adipose tissue and relationship with body fat composition. Endocr Res 2004;30(2):247-55.

19. Garduño-GarciaJde J, Alvirde-Garcia U, López-Carrasco G, et al. TSH and freethyroxine concentrations are associated with differing metabolic markers in euthyroidsubjects. Eur J Endocrinol 2010;163:273-8.

20. Park SB, Choi HC, Joo NS. The relation of thyroid function to components of the metabolic syndrome in Korean men and women. J Korean Med Sci 2011;26:540-5.

21. Iqbal A, Jorde R, Figenschau Y. Serum lipidlevels in relationto serum thyroid stimulating hormone and the effect of thyroxine treatment on serum lipid levels in subjects with subclinical hypothyroidism: theTromso Study. J Intern Med 2006;260:53-61. 